\title{
THE IMPACT OF THE INTRODUCTION OF ARTIFICIAL INTELLIGENCE IN ADVOCACY: SKILLS AND PROFESSIONAL ETHICS NECESSARY FOR THE FUTURE LAWYER
}

\section{O IMPACTO DA INTRODUÇÃO DA INTELIGÊNCIA ARTIFICIAL NA ADVOCACIA: AS HABILIDADES E A ÉTICA PROFISSIONAL NECESSÁRIAS AO FUTURO ADVOGADO}

\begin{abstract}
Recebimento: 1 maio 2020
Aceitação: 19 abr. 2021

Mateus de Oliveira Fornasier

Doutor em Direito

Afiliação institucional: Universidade Regional do Noroeste do Estado do Rio Grande do Sul - Unijuí - (Ijuí, RS, Brasil)

Lattes iD: http://lattes.cnpq.br/3316861562386174

Email: mateus.fornasier@unijui.edu.br
\end{abstract}

Como citar este artigo / How to cite this article (informe a data atual de acesso / inform the current date of access):

FORNASIER, Mateus de Oliveira. The impact of the introduction of artificial intelligence in advocacy: skills and professional ethics necessary for the future lawyer. Revista da Faculdade de Direito UFPR, Curitiba, v. 66, n. 2, p. 69-94, maio/ago. 2021. ISSN 2236-7284. Disponível em: https://revistas.ufpr.br/direito/article/view/73458. Acesso em: 31 ago. 2021. DOI: http://dx.doi.org/10.5380/rfdufpr.v66i2.73458.

\begin{abstract}
This article studies the application of artificial intelligence (AI) in the professional environment of lawyers, analyzing advantages, risks, and future professional perspectives. As results of the research, it was found that an adaptive, resilient professionalism that demands transdisciplinary and human capabilities of lawyers, in a complex way, is what is expected of the successful lawyer in the future with AI. In this sense, the professional field will undergo several changes with regard to activities of a repetitive and formal character, and the activities that should be more valued from now on, in addition to technical-legal knowledge in line with the technological development, are consultancy and legal advice. With regard to professional ethics, these technologies, as well as their potentials and risks, must be understood by professionals, so that they become aware that their use may be mandated by the rules of professional ethical conduct (due to the precision they bring to legal advice), but much of the current codifications of professional ethics should be changed due to the specificities of AI. This work used the hypothetico-deductive method, a qualitative and transdisciplinary approach, and bibliographic-documentary research technique.
\end{abstract}

\section{KEYWORDS}

Artificial intelligence. Legal services. Professional deontology.

\section{RESUMO}

Este artigo estuda a aplicação da inteligência artificial (IA) no ambiente profissional da advocacia, analisando vantagens, riscos e perspectivas profissionais futuras. Como resultados da pesquisa, temse que um profissionalismo adaptativo, resiliente e que demanda por capacidades transdisciplinares e 
humanas dos advogados, de modo complexo, é o que se espera do advogado bem-sucedido no futuro com a IA. Nesse sentido, o campo profissional sofrerá diversas transformações no que tange a atividades de caráter repetitivo e formal, devendo ser mais valorizadas, para além do conhecimento técnico-jurídico em consonância com o desenvolvimento tecnológico, as atividades de consultoria e aconselhamento jurídico. No que tange à ética profissional, essas tecnologias, seus potenciais e riscos, devem ser compreendidos pelos profissionais, de forma que venham a perceber que seu uso pode vir a ser obrigatório pelas regras de conduta ética profissional (em razão da precisão que podem vir a oferecer ao aconselhamento jurídico), mas muito das codificações da deontologia profissional atuais deverá ser alterado em razão das especificidades da IA. Utilizou-se neste trabalho o método hipotético-dedutivo, com abordagem qualitativa e transdisciplinar e técnica de pesquisa bibliográficodocumental.

\section{PALAVRAS-CHAVE}

Inteligência artificial. Serviços jurídicos. Deontologia profissional.

\section{INTRODUCTION}

The research "O Futuro das Profissões Jurídicas” (“The Future of Legal Professions”), conducted by Silva, Fabiani and Feferbaum (2018) pointed out that many characteristics of mass litigation - mainly the pressure for price reduction in the provision of services, high costs of managing a large number of processes, redundancy and replication of the arguments presented in the profuse demands, the expectation of reducing the amount of human errors due to the automation of work routines and the possibility of better viewing and reporting the services performed to clients - have been encouraging the adoption of technologies for legal services. It also pointed out that the replacement of human professionals by new technology devices will mainly reach positions of lower hierarchy (junior lawyers, interns, paralegals, administrative assistants, etc.). In this process, there has also been occurring the incorporation of professionals without legal training to legal organizations (such as production engineers, computer scientists and technicians, etc.). And, finally, new technologies will be integrated in the elaboration and provision of legal services - among them, software and artificial intelligence (AI) devices.

The use of $\mathrm{AI}$ in advocacy is no longer new. ROSS, known as the robot lawyer" of the ROSS Intelligence company, has already offered AI-driven research to law professionals since at least 2016. Several other companies also provide lawyers with legal support services with AI (legal research, contract review, litigation strategy, financial litigation decisions, electronic discovery and jury selection, for example), and the use of such tools is gradual and slowly being accepted among professionals (TURNER, 2016). AI promises greater efficiency, but it frightens anyone who worries about replacing humans with robots (JACOBOWITZ; ORTIZ, 2018, p. 408-409). In fact, automated systems such as DoNotPay, developed by a British teenager, "represented” customers in around 
160,000 (one hundred and sixty thousand) (successful) traffic ticket disputes (MCGOOGAN, 2016), demonstrate that some of these fears are not unfounded.

To study the use of AI in law services is something of great relevance today. First, due to constitutional principles pertaining to the relationship between citizens and justice (such as legal safety, human dignity and access to justice), they may be affected (sometimes positively, sometimes negatively) by the use of this technological form. Services may be performed more precisely, in less time and with lower prices can be provided by well-conducted and regulated use (including professional ethics) with technology. On the other hand, there is a great potential for perpetrating prejudices (racial, ethnic, gender, etc.) through the use of such devices. Also, the misuse of technology can break important legal duties of the lawyer, such as diligence, competence and confidentiality.

Given this context, the following question arises as a problem that led to this research: how should legal professionals conduct their careers and practices, in order to guarantee not only professional survival, but also, in an ethical way? As a hypothesis to such a problem, it is initially that lawyers should adopt transdisciplinarity and resilience as tonics of their conduct, the first of which will allow them to understand not only the risks that the use of technology can provide, but also, its advantages; and the second will bring them, along with the ability to see their environment in a less inaccurate way brought about by transdisciplinarity, the possibility of always absorbing new knowledge and professional possibilities that technology can bring. However, there will be a major transformation in their professional environment (with a large substitution of various tasks for technology), reallocating professionals to tasks more suited to consultative activities than to litigation, and this will require the use of technologies to provide more reliable services.

The main objective of this article is to study the application of AI in the professional environment of the legal profession (in the office” space, through the attorney-client relationship, and also in the relationship between professionals), analyzing advantages, risks and future professional perspectives. In order to operationalize this general objective, the development of the text was divided into three sections, each one corresponding to a specific objective. The first section aims to analyze the ways in which AI can be applied in the practice of lawyers, representing economic, operational and legal advantages. It also used an analysis of what would be the main technical obstacles of such technology, translated into legal issues. The second part, on the other hand, is dedicated to present skills that the future professional of law must develop in that scenario of expanding application of AI to legal activities. Finally, its third section focuses on analyzing ethical-professional issues pertaining to both the application of AI by lawyers - that is, what principles and rules of professional deontology of lawyers could be violated in the use of such 
technology - and to the AI's own operation as a legal consultant or executor of tasks until now related to lawyers, interns and paralegals.

In terms of methodology, this research has an exploratory nature, using the hypotheticodeductive method, a qualitative and transdisciplinary approach (since, at certain times, it was necessary to use typical reasoning in computer science, business management and economics to analyze issues related to practice and ethics in law), and bibliographic-documental research technique.

\section{POSSIBILITIES AND RISKS OF THE USE OF AI IN ADVOCACY}

The business model of many law firms, and also of legal professions in general, will face a considerable paradigm shift, as the services provided in the form of billable hours largely consist of tasks that do not require a higher legal education, involving mere data processing (KERIKMÄE; HOFFMANN; CHOCHIA, 2018, p. 91). Legal technology (or LawTech), in this context, represents a wide range of solutions that affect lawyers and clients at various levels.

For several decades, technological automation has been gradually occupying an increasing role in advocacy tasks, resulting in the current situation in which, especially the search for precedents, the generation of documents, the creation of summaries and court documents, and the predictive analysis of trial results are technically executable by machines. When adopting these technologies, lawyers do so for the cost-benefit reasons (to save time and human resources), and society appreciates new mechanisms, which help to avoid extrajudicial elements in guaranteeing the rule of law, in addition to promising greater predictability of legal decision (legal certainty) (KERIKMÄE; HOFFMANN; CHOCHIA, 2018, p. 105-106).

But the success of a century of business models of traditional law firms, which have few motivations for reform, strictly hierarchical structures, still led, in most cases, by non-digital natives, and featuring the inherent interest in maintaining the opacity of law and advocacy with a focus on maintaining the monopoly of these services, has been obliterating a reasonable adaptation of law to technological potentials. This resistance to change also corroborates the widespread fear that intelligent machines (which would be too positivist, unable to assess human values, ethics and the living nature of law) will replace human professionals.

In addition to encouraging the symbiosis between machine work and human labor in advocacy - which will benefit society and clients with less expensive, more accessible and transparent services - it must be understood that the automation of several of the legal tasks means much more a 
transition to new forms of work than the end of the profession (and this has occurred with technological progress in all professions).

AI techniques developed in a first wave" (systems based on trees of knowledge and decision developed from the prospecting of the knowledge of human specialists, which started as early as the 1980s), together with the popularization of advanced computing, allowed the creation of underlying techniques that are still widely used today (in document automation and online legal services offered by law firms, and in the tax compliance sector, for example). But a second wave" of AI is in vogue today - and three types of systems are becoming crucial currently (SUSSKIND, 2017, p. 186-187): - $\quad$ machine learning operating on the big data formed by the huge bodies of legal materials electronically available (some systems can already make more accurate predictions of the outcome of legal proceedings than those of specialized lawyers) ${ }^{1}$;

- $\quad$ systems that answer legal questions and solve problems in an apparently intelligent way;

- $\quad$ affective computing, which supports systems for detecting and expressing emotions, capable of differentiating between false and genuine facial expressions with more reliable results than human specialists.

As the capabilities of machines increase, they will gradually replace human lawyers. Although the best professionals (specialists who perform irreplaceable tasks for machines) may last longer in the market, there will not be enough space to keep armies of traditional lawyers active. The decade of 2020, at least, will not be one of unemployment for human lawyers, but of relocation (lawyers carrying out different functions). During this period, lawyers will have to plan ways to compete with machines (looking for legal jobs that favor human capabilities to the detriment of AI) or build machines (to become directly involved in the development and provision of new services, technologies and systems). But in the long run, it is difficult to foresee anything other than a much smaller need for conventional lawyers (SUSSKIND, 2017, p. 188).

There are three narratives about the role of technology in relation to the current legal services environment: increase (according to which, the true professional will adopt the technology and remain the same lawyer), disruption (in which the lawyer changes or perishes) and shutdown (according to which technology will make lawyers perish), each giving life to specific professional archetypes

1 In the last five years, the development of the Legal Judgment Prediction (LJP) - automated prediction of the outcome of a judicial case, based only on the case documents - has been developed by researchers from the most varied countries, having obtained good results in relation to Supreme Courts of the European Union, France, and China (STRICKSON; IGLESIA, 2020, p. 204). The LJP has several applications in the real world, such as a prediction system that can be used in the stage of making the judgment and the identification of the most important words and phrases within a judgment. Strickson and Iglesia's AI performance, related to forecast results based on a data set containing 100 years of UK labeled court sentences and machine learning, reached 69.05\%. 
about how lawyers react to LawTech (WEBLEY et al., 2019). But such narratives have at least two problems: first, they are simply predictions, based on analogies to events outside the law, and not prophecies; second, they become, at least in the popular imagination, great ideas that cover all of the lawyer's work - which is, in fact, historically, culturally, ethically and operationally diverse, even among local communities of practice.

Thus, to these three narratives, a fourth can be proposed, that of adaptive professionalism”, which emphasizes the complex and contextual nature of the legal professional field - taking into account the cultural, historical, social and practical differences of each community of professionals to analyze how they can adapt to technology. With adaptive professionalism, lawyers can access the benefits of technological developments, while remaining attached to essential notions of ethical conduct, access to justice and the rule of law. And also, to have foundations on which they can build their ethos and practices within LawTech futures. The development of LawTech can facilitate access to justice, including removing many of the costs involved in legal services. Furthermore, dubious regulation, the elaborated monopoly, and the formulation of ethical advocacy guidelines in the form of codes of conduct are a normative situation that needs to be changed. A different view of law shows that there is much to be gained by analyzing what human lawyers do today and discovering how technology can enable better practices, rather than simply following a story about the need for replacement lawyers.

AI research tools have several advantages over traditional research methods, as they allow the analysis and review of large data sets and are able to identify patterns that are imperceptible to human researchers. But it is too early to know whether people will be replaced by machines in the legal sector. Currently, the application of AI is not free from dangers because, due to its complexity, such systems can escape the control and understanding of their operators and programmers. Especially when performed by researchers with insufficient information technology knowledge, AI research can result in distorted analyzes and flawed research. Thus, a series of quite interfering problems in the results of AI operations is presentable. The main ones can be described as follows (YU; ALÌ, 2019, p. 3-5):

- $\quad$ algorithmic bias: since algorithms encode human choices about how decisions should be made, they are not immune to the values of their creators - and can also reinforce human prejudices; 
- $\quad$ data bias: bad or defective data sets used by AI can cause them to identify recurring patterns in data sets and predict based on those patterns - reiterating and expanding data set prejudices, even when unknown by humans ${ }^{2}$;

- $\quad$ inference and prediction: algorithms are very bad at distinguishing between causation and correlation, and therefore, there is always a risk of making conclusions based on wrong inferences. Analysis models can also make assumptions, substitutions, or incorrect assumptions of causal relationships that do not really exist;

- $\quad$ limitations of input and output of information: there are still significant morphological and semantic challenges regarding the understanding of human language by AI systems - especially when languages other than English are involved;

- $\quad$ unpredictability: AI systems are capable of surprising behavior, sometimes due to external inputs, sometimes due to their own internal structure. Such systems learn by themselves through trial and error processes, and currently, AI can teach itself how to perform complex tasks. However, developers don't know how the algorithms used by these systems operate - and learning machines can self-reprogram to the point that even their programmers are unable to understand the logic behind AI decisions.

As potential solutions to these problems, the following measures are present (YU; ALİ, 2019, p. 6-7):

- $\quad$ education: law courses must recognize the trend towards the use of AI and create new programs to teach the next generation of lawyers both to use these platforms and to dialogue intelligently with the people who build them;

- $\quad$ service audit and classification: they serve to validate and certify the quality and accuracy of AI systems, making use of investigative processes based on statistics to deal with unknowns and limitations of commonly used data in AI systems;

- $\quad$ algorithmic transparency: development of legal means to compel AI developing companies to release some important information about their algorithms, in order to detect possible biases;

2 Concerns about gender bias in word incorporation models have captured substantial attention in the research literature on algorithmic bias. Other types of bias, however, received lesser amounts of scrutiny. David Rozado (2020) carried out a large-scale analysis of associations of feelings in popular models of word incorporation designating gender, ethnicity, socioeconomic status, age, physical appearance, sexual orientation, religious feeling and political tendencies. As a result, the researcher found systemic bias against known names among African Americans in most of the examined models of incorporation. Also, that the gender bias in the incorporation models is multifaceted. Furthermore, new types of prejudice not previously reported in the scientific literature have also been identified (in relation to the middle class and the working class, having male children, the elderly, a clear physical appearance, the Islamic faith, non-religiousness and conservative political orientation). 
- $\quad$ self-explaining AI: since AI learns from the surrounding environment and past mistakes, even its programmers struggle to understand its internal decision-making logic. That is why it is dangerous to blindly outsource moral decisions to machines. Understanding the internal logic of AI, therefore, is a first step to guarantee full responsibility for computational legal research and automated legal decisions, and AIs that explain its logical processes should be developed ${ }^{3}$.

In order to avoid the problems listed above, a set of good practices for lawyers and researchers in law and AI can be summarized as follows (YU; ALÌ, 2019, p. 7):

- use of multiple AI systems: different legal databases will give different results for the same questions, as each AI shows unique characteristics. The comparison between various types of results by researchers, in order to detect flaws in AI, would increase the accuracy of the research;

- experiment with different inputs: since AI systems are generally structured as natural language processing software (which calculate the probability with which words can be found next to each other based on statistical inferences), multiple queries using different keywords must be run, relaxing time constraints, or rephrasing the question asked of the software, which can help detect biased, as well as inaccurate or flawed search results;

- human monitoring: combined with all of the above techniques, common sense and human control can help identify biased content delivered by the machine.

\section{THE NECESSARY SKILLS OF THE FUTURE LAWYER IN THE CONTEXT OF AI}

Many challenges have been faced by the advocacy in recent years - which seem to confirm suspicions that such an occupation is in an irreversible decline (and could be evidenced by the decline in the numbers of those enrolled in law courses, higher unemployment rates for graduates, and technological advances that increasingly threaten the livelihood of lawyers); but Yoon (2016, p. 456) brings a more optimistic view about the future of the profession. While technology has really contributed to many current challenges in the legal workforce, its advances have so far focused on automating routine tasks for lawyers (such as the search for words, expressions and their legal meanings). The latest technologies (still in their early stages) focus on facilitating the ways in which

3 Several examples of specialized literature on the development of self-explaining AI can be read in SADO et al., 2020. 
lawyers analyze more complex legal issues. In this sense, AI technologies would reduce the cost of legal services for both lawyers and litigants, democratizing access to legal services.

The most recent technology is not focused on replacing the routine tasks of lawyers yet, but rather on facilitating the understanding and analysis of legal material, improving the services that lawyers can provide - and the production of services using these technologies does not depends very much on the economy of scale of large law firms, and also capacitates individual professionals and small business lawyers. If emerging technologies automate routine tasks for lawyers, the problems of the profession would undoubtedly be permanent, since their effect would be mainly related to largescale transactional or litigation practice. These technologies would thus be beneficial to large law firms. But the individual lawyer (or one who works in a small office) will experience a declining market, as technology will replace him/her in some of the tasks usually done by human lawyers (preparation of declarations of will or contracts, for example), but without offering corresponding opportunities to expand his/her practice.

There is little doubt that technology will replace some of the tasks typically performed by lawyers (and a recent example of this is the online platform of lawsuits) (YOON, 2016, p. 465-467). In addition, many of the new technologies used in the legal professional sphere reflect an evolution from AI (which means the use of computing to replicate tasks performed by humans) to increased intelligence (a symbiotic relationship between humans and technology), in which humans continue to perform tasks, but they do it interactively with technology in order to improve it.

Companies are already developing technologies capable of understanding and answering complex legal questions, and their answers depend on several factors - mainly applications that use machine learning, legal big data analysis, and neural computing to textually analyze all relevant sources and provide a probabilistic answer to that question. Thus, knowing how to qualify a legal relationship to analyze its suitability for different aspects of law, for example, is something perfectly achievable by such applications. For lawyers who, beyond dogmatic classifications (between fact, law and jurisprudence for drafting documents/petitions, for example), also engage in other substantive areas of law (such as tax planning or mediation, for example), technologies that perform dogmatic classifications are closer to the increasing intelligence, freeing the lawyer to focus on more complex legal issues. However, for those whose experience and expertise are limited to such dogmatic classifications, the technology in question will be treated as an AI apparatus that will most likely replace them.

Much of the study of the impacts of new technologies on employment relationships has focused on jobs/functions that are considered repetitive and that require minimal skills. However, the 
opposite has now been suggested as well - as new software develops, it may come to perform at least some of the functions of various professions commonly considered to be more complex, including law. Discussions about the impact of new technologies on the practice of law are not driven by technological determinism. Criticisms of the content, practice and priorities of legal education have existed for many years. What is perhaps being witnessed today is, on the one hand, a debate about the facilities that technology brings; and on the other, a debate driven only by the advent of these new technologies (SIMPSON, 2016, p. 50-51).

According to some views, professional work (including that of a lawyer) involves much more judgment, evaluation and talent than what algorithms and machines are capable of replicating. However, this view may not be recognizing the extent to which legal work is actually repetitive and structured in a way that can be easily (and better) done by new forms of technology. The ways in which technology affects the legal profession is an issue much more complex than simply discussing about algorithms. The facilitation that technologies have brought to the media, for example, has allowed outsourcing of legal work. The continued training of lawyers in other countries through online learning facilitates this process, thus reconstructing the locus where the professional is inserted (SIMPSON, 2016, p. 54).

It would be a mistake to assume that the adoption of new technologies in the practice of law is conducted exclusively by the new technological means adopted. Technology itself is driven by several factors - including the desire to make access to law cheaper. This means that there is an impulse to adapt the law itself to accommodate that desire, which can have both positive and negative aspects. The adoption of algorithms for legal consultation, conflict resolution and standardized sentence delivery can indeed decrease the price charged for the services provided by the most varied legal professions, but such software (even when qualified by machine learning techniques and big data analysis) will frequently be challenged by the contingencies of individuals and cases submitted to justice (SIMPSON, 2016, p. 56).

There are other optimistic positions (although they point to the need for adaptation by lawyers), according to which lawyers will not be replaced by AI for empirical and normative reasons (MARKOVIC, 2019, p. 325). Firstly, most legal tasks are inherently abstract, not being enforceable even by advanced AI (which includes deep learning techniques). In addition, there has been a trend, over the past twenty years, of steady increases in both jobs and lawyers' salaries (at least in the USA), demonstrating that the legal profession has benefited from new technologies. Finally, if large-scale automation of legal work were possible, it would not be advisable due to the main values of society 
- which are not merely aspirational, being reflected in the multifaceted role of lawyers and in the way the legal system is structured.

Much of the discourse around the law/AI relationship provides an impoverished understanding of both the possibilities of AI and the real work of lawyers (MARKOVIC, 2019, p. 349). Although AI is also changing legal practice, most advocacy-related tasks are not suitable for automation. Only among segments of the legal profession that provide routine and formulated solutions to clients will the emergence of intelligent machines induce anxiety.

It is precisely in the work team of non-lawyers (paralegals, administrative and auxiliary services) that automation will have the greatest substitutive impact. AI is thus likely to benefit lawyers by freeing them from low-profit jobs (for example, document review), allowing them to focus on their core tasks - support, advice and advocacy; compliance with the law and help to protect the public interest. In addition, lawyers can be held legally responsible for their representations when the services are not well performed.

Whatever the potential capabilities of intelligent machines may be, lawyers play a multifaceted, complex and invaluable role in the legal system. They support and advise their clients, enforce the law and help protect the public interest. The legal system is not limited to simpler functions, such as the collection of traffic tickets, and the reckless automation of all part of the legal work is bound to destabilize the system. Thus, there is a need for lawyers to work together with AI to better serve the public, rather than fearing obsolescence.

Given this situation, one of the most important skills for a future lawyer (and other legal professionals) is critical legal thinking enhanced by sufficient technical knowledge, so that they remain adequately skeptical about what exactly new technologies offer and what their limitations are (MOSES, 2018). Legal knowledge and skills will continue to be an important component of broad technological assessment and responsible innovation, especially where technology changes the way law, legal information and solutions to problems of this nature are formulated, accessed and used. This ability is the best protection against unfair applications and bad risk assessment tools, for example. Thus, there is a need for lawyers who appeal against inappropriate uses of data analysis and expert systems in decision-making, and who maintain essential values of the rule of law, even when pressured by scenarios of demand to increase efficiency in resolving disputes. Perhaps in the future there will be fewer lawyers - but legal knowledge and skills, enhanced by technological literacy, remain crucial.

In the view of Smith and Spencer (2020, p. 18), the lawyers of the future will have to assume a polytechnic” or multi-talented” character, being their legal experience applied to the changing 
world in an increasingly agile way, and within a variety of organizational settings. In the long term, it is suggested that, in the education of this future professional, it is necessary to develop basic skills in legal principles based on the study of design and logic, instead of learning specific technologies that can be replaced soon.

It is necessary, therefore, a balance, in legal education, between understanding the impact of changing roles in law firms and the demands of the internal dynamics of the legal organization and legal advice. Future lawyers therefore need to experience higher education much more like an apprentice program (that is, to value practical education through initial experience in the workplace). Universities, therefore, must reflect deeply on how they can contribute to the development of young polytechnic” or highly skilled” lawyers. In particular, it is necessary to focus on the way in which an educational institution produces qualified graduates, with creative thinking, who recognize problems before they occur, and capable of designing systems, processes and solutions built to work well.

The development of AI is still in the primary stage of weak AI” (systems that can perform repetitive, routine tasks, but cannot be described as being conscious) - so, at the present moment, it would be an exaggerated alarmism to aim for the general replacement of humans by AI. However, in the long run, the hypothesis of replacing humans with AI systems, depriving them of employment opportunities, is not unfounded from a scientific and technological point of view - and this type of concern serves as a driving force for current scholars to study the AI. The ultimate form of AI's impact on advocacy can come from the complete replacement of human professionals by such technology. Thus, the answer to questions about how human robots can become, what responsibilities and rights they can have, and how acceptable to people can the work of robots be in situations that demand the defense of people's rights (or judgment about of their lives), should not be limited by technological development (HU; LU, 2020, p. 968). Philosophy (mainly with regard to ethics) and law should be fields concerned with these issues, in a transdisciplinary way towards general science and technology.

But lawyers will not take advantage of these opportunities by learning to code - rather, it will be necessary to develop interpersonal skills, understanding the emerging and user-centered business world, engaging with curiosity and creative problem-solving skills, listening carefully to clients and openly engaging with the changing world in which its customers operate and with the leadership dynamics that govern this operation (SMITH; SPENCER, 2020, p. 18). Technologies will support lawyers in those tasks, but according to emerging trends, technology will not have easy and accessible programming codes over a three to five year period. That is, the lawyers of the future will 
interact with technology, not design it. Therefore, the sooner aspiring lawyers are exposed to the realities of this interaction through experimental learning, the more prepared they are to face the future of legal practice.

Lawyers in the AI era must recognize that they need not only in-depth legal knowledge and skills, but also an understanding of data, technology, project management and process improvement to be competent legal professionals (CARREL, 2019, p. 1153). They should also always look out for other lawyers and students to expand their training and start learning about AI, design thinking, data analysis and more. However, although it is essential to combine deep knowledge of law with broad knowledge in technologies, it is necessary to develop emotional intelligence in decision-making and problem solving.

Success in advocacy must also recognize the changing nature of that career: the role of the lawyer will no longer correspond to just researching and technically analyzing the law, but also encompassing the ability to explain the results generated by AI to clients in a satisfactory manner. This model should also reflect new and evolving careers in law (for both lawyers and auxiliary professionals). Carrel (2019, p. 1174-1175) has thus been developing a competency model called the “Delta Model”, to enable a more holistic understanding of a successful legal professional. This model comprises three competencies that represent knowledge: skills related to the law; personal effectiveness resulting from emotional intelligence (including resilience in the face of greater and faster changes, and the ability to work with others, including other areas of knowledge); and the business/operational aspects of the practice of law, such as technological tools.

Lawyers will still have to understand legal norms (principles, rules), but perhaps differently from what currently occurs (FLOOD, 2019). Furthermore, increasing the breadth and intensity of coding skills among non-IT people may seem attractive, but the main rewards for good programming necessarily go to the best coders, not to those who have inadequate skills. And in any case, teaching how to code in great details can become redundant, as machines learn to code themselves.

The essential skill for future lawyers is that of consulting - a skill that was underestimated during the 20th century. Due to the changing nature of law, from long-term relationships with clients to ad hoc transactioners with a focus on different task sets, the demand hitherto has been for lawyers with specific skill sets (securitization or mergers and acquisitions, for example), at the expense of the advisor/consultant. Tasks like document production (in the most varied areas) lend themselves to automation through machine learning - and even complex tasks with minimum rules can be taught to machines through a self-learning reinforcement process. And the production of documents (including smart contracts) associated with blockchain technology are logical trends. 
The reduction in the number of lawyers and the automation of even more tasks related to the profession will, in the future, provoke an increasing need for professionals able to see the greater picture" and carry out comprehensive risk analyzes (valuing, here again, the transdisciplinary character developed personally). Then, there will be at least two complimentary directions about the profession (FLOOD, 2019):

- $\quad$ automation: which implies denying the need for human emotivity, resulting in increasing confidence in automated processes. This trend is suitable for tasks such as compliance, where most tasks refer to just checking for the presence of predetermined requirements, almost like filling out a form;

- $\quad$ humanization: the ideals of trust are reintroduced through the relationship between client and consultant/counselor, which is necessarily built on interaction, exchange and affection. The lawyer's ethos, in this sense, is again characterized by credibility and character - skills that are little (or not) taught in law courses. Thus, it would be necessary for lawyers to create and expand their ethos in the context of professionalism. Trusted consultants will be in high demand in a world full of populism and nationalism, as someone must be able to communicate about these limits and connect with those on the other side. And lawyers, having the language as their basic tool, are ideal for these roles.

Repetitive and routine jobs are increasingly being redesigned, in the sense of outsourcing or automation (to varying degrees), and AI will have a similar impact on objective/descriptive” legal tasks, and even on some subjective/non-subjective descriptive functions”. In this sense, machine learning and other AI technologies introduce the opportunity to explore a company's main strategy and vision of the future, allowing preventive legal practice, thus elevating the legal function to strategic status (TUNG, 2019, p. 402). Thus, it has to be said that AI will shape how the legal services sector should redefine and redesign itself. A very illustrative list of tasks in which lawyers could be inserted in business strategies is listed by Tung (2019, p. 400):

- $\quad$ to institute legal strategists who understand, simultaneously, advocacy, strategies and business operations, to fill the gaps between law and business management;

- $\quad$ to redesign legal tasks, making data available to leverage predictions based on machine learning - creating data and analysis on communication with competitors, from allowed contacts to suspects under antitrust rules, in order to help provide timely guidance based on competition policies of a company;

- $\quad$ to invest in business cases for training algorithms to predict options through collaborations between specialists in law, strategy, operations, processes, IT, data analysis, deploying behavioral sciences in conjunction with data analysis to identify incidents of fraud or malpractice, and design 
effective reminders and warnings to prevent legally incorrect actions from entering companies' managerial and productive processes;

- $\quad$ to charge corporate legal strategists to design flows related to the internet of legal things (IoLT), based mainly on digital contracts, autonomous vehicles and behavior prediction science, integral to the institution's data architecture - maintenance of risk controls and legal costs, to help lawyers and companies to increase risk pricing in the context of opportunities (from traditional credit risks to the implementation of business models that do not yet have clearly applicable laws);

- $\quad$ to balance the deployment of human resources and capital in the legal function, starting with the automation of repetitive and well understood commercial and legal tasks, not only to reduce costs, but also to generate data from these tasks, such as business consultations on certain risks to help providing cost reduction accounting as well as information about a company’s risk profile;

- $\quad$ to recruit and train professionals in all ranks of the legal function, thereby simplifying business strategies and most aspects of operations, but still offering the corrective side of legal risk management.

\section{THE PROFESSIONAL ETHICS OF THE LAWYER REGARDING THE USE OF AI}

Huge global companies and in-house corporate legal departments, where AI is being promoted and developed, already complicate the ethical practice of lawyers. Professionals may not be able to choose whether to use automated systems in their work, or not have the opportunity to understand how these machines really could work. In this scenario, the combination of professional rules, general legal system and the context of AI development and regulation may not be enough to influence the responsible use of this technology by lawyers (ROGERS; BELL, 2019). Apparently, few clarifications, educational and regulatory guidelines are being offered to legal professionals, what especially increases the complexity of awareness and judgment about how to act. Ensuring the adherence of lawyers to the established standards of ethics and competence requires capacity and motivation for individual professionals and workplaces. This includes the skill and motivation necessary to continue fighting for a professional identity and to be subject to statutory and disciplinary regimes in addition to those applied to non-professionals.

Ivey (2020, p. 137-138) considers three ways by which lawyers could help their clients prepare for the AI revolution, while remaining within the ethical boundaries required by the profession, and achieving legal objectives related to the rule of law. Firstly, professionals could help shaping advice and policies by learning about technology and defining terms and standards, keeping 
clients away from dangerous legal "black holes” related to AI use and, when appropriate, preventing clients, through advice, from carrying out certain conduct (even when that revolts the customer momentarily). Secondly, lawyers could help clients to assess appropriate relationships with the technology sector, identifying and learning from bona fide experts, and appreciating some mutual skepticism between governments and technology developers. Finally, lawyers could monitor AI developments taking place in other countries to prevent temptations to take shortcuts to catch up.

An AI system applied to the legal services can be used, for example, to extract relevant passages from the jurisprudence that deals with the meaning of written norms, as well as the principles and policies underlying them (NUNEZ, 2017, p. 203). However, developing a professional role can be an obstacle to such systems, as the professional role of a lawyer is exclusive to the human, just as morality is individually human. In addition, while there are compelling arguments that articulate the importance of not considering individual morality when providing legal advice, there are statutory norms that explicitly require consideration of the attorney's professional and moral judgment. Thus, there are serious doubts about how an AI could proceed when issuing an opinion that requires research, for example, regarding respect for morals and good customs in a situation of probable loss of family power (Brazilian Civil Code, art. 1638) (BRASIL, 2002) or the impossibility of registering a constitutive act of a legal entity that may have its object considered contrary to morals and good customs (art. 115, Brazilian Public Records Law) (BRASIL, 1973). Or else, how should one proceed with the requirement of moral integrity, essential for the registration of an individual in the ranks of the Brazilian Bar Association (Ordem dos Advogados do Brasil, OAB), according to the Statute of $\mathrm{OAB}$, regarding to $\mathrm{AI}$ ? Or with the requirements relating to public, professional and individual morals, according to the OAB Code of Ethics and Discipline?

Of course, AI systems are able to learn from experience (especially in a trial and error process) without being explicitly programmed - and, after a period of time, an AI could learn how to deal with issues that require the use of professional judgment and moral, consistent with the spirit of the law firm in which it is being employed. As a result, it may be reasonable to assume that AI will eventually develop a certain morale - including with regard to good professional practices. But how should one proceed if an AI disrespects a professional moral rule - the AI (which has no legal personality, but develops moral rules based on deep learning) or the law firm in which it is used would be guilty? These are issues that advocacy codes of conduct around the world will have to seek to clarify over time.

The lawyer-client professional relationship is traditionally governed by a specific set of rules that constitute the legal framework for providing professional advice - and those standards aim to 
ensure the provision citizens with reliable, comprehensive and accurate advice to make important decisions in life (HAUPT, 2020, p. 666). But this regime does not exist specifically (yet) in the case of legal advice provided by AI. Thus, a first step in the regulation of professional AI should be to use the existing legal framework that regulates professional consultancy, since this, by focusing on the lawyer-client relationship, places the regulatory access points through which law could achieve the goal of ensuring good advice, whether by human lawyers or by AI. However, there will be several points related to professional advice provided by AI that will require significant changes to the existing rules of conduct.

Rules of professional conduct for lawyers are an important framework for protecting clients from legal services. However, many people have been excluded from legal services (due to lack of resources, for example). AI, as seen above, has been championed as having the potential to bring a new era of legal services, as it could provide one-to-many” legal assistance, and data-driven legal analysis could also provide new insights to customers. In many cases, such as regarding to confidentiality duties, codes of ethics in law could also protect consumers of legal services in relation to the use of AI. But there is a clear need to update the advocacy codes of ethics. Lawyers will increasingly render their services with software of the most varied natures, and new details in the protections will be necessary for the safety of clients. Furthermore, it will also be important to define more clearly what constitutes legal practice”, so that innovators and law firms could have safety in innovation (WALTERS, 2019, p. 1091).

Special problems remain with regard to AI in legal practice. Particularly, when AI tools reach conclusions, they should be able to explain to lawyers and judges how those conclusions were reached, as well as what data they were based on, so that human lawyers can exercise their functions of supervision on machines. Lawyers and judges cannot protect clients from prejudice, for example, if their AI is little more than a "black box" that produces legal conclusions.

Codes of conduct (especially that of the OAB) do not explicitly prohibit the use of AI or data analysis by lawyers - in fact, the duties of competence and diligence will increasingly demand that lawyers use such tools. AI and data analysis can provide empirical and objective responses to important client inquiries, and it may no longer be ethical for law firms to use conjectures or guesses in providing legal services to clients. Therefore, far from banning AI and data analysis, codes of professional ethics in law can increasingly demand their use.

It is possible to use AI systems competently - as those systems could be framed in a similar way to the ethical guidelines established for the outsourcing of legal services (JACOBOWITZ; ORTIZ, 2018, p. 417-418). The American Bar Association (ABA) and several US states issued 
advisory opinions on the matter between 2006 and 2012, which can guide lawyers who outsource legal research, document review and petition drafting. And the State of New York released an advisory opinion on outsourcing the administrative functions of a law firm. Such opinions mainly discuss the outsourcing of legal services to other human beings, generally allowing the practice when carried out in accordance with the rules of professional conduct and, comparing with the norms pertaining to the OAB's Code of Ethics and Statute, one can observe compliance with these principles: competence (art. 34, XXIV, XXV and XXVII of the OAB Statute), diligence (idem), communication / information (art. 8 of the OAB Code of Ethics), confidentiality (arts. 24 to 26 of the same Code) and supervision by other lawyers - mainly with regard to obtaining the client's consent before using outsourcing (which refers to art. 8 of the OAB Code of Ethics) (BRASIL, 1994, 1995).

Advocacy must take a comprehensive approach to ensure that $\mathrm{AI}$ is responsibly and ethically integrated into legal services. Part of that approach must contain emerging solutions of legal selfservice - because if restrictions to such practices occur, the development of a great revolution of law by AI may be compromised, so that the big companies that develop technology would be favored in detriment of the wider public interest. Furthermore, challenged as they are by this new technological form, communities and legal entities must urgently initiate a solid dialogue, so that they can guide professionals when ethical issues arise from the use of AI systems in legal practice. The list below can be a starting point for this dialogue and guidance (SIMSHAW, 2019, p. 212-213):

- $\quad$ competence: lawyers must be required to be involved in the design of the AI systems they use, or at least to understand (with the help of an expert, if necessary) certain underlying characteristics that affect them - such as AI bias and the limits on the use of AI (in relation to observational data and those resulting from the exclusion of information that has not been collected);

- $\quad$ confidentiality: protecting confidentiality with customers' data in the AI era should include, in addition to security devices, understanding how AI systems work, communicating with customers to understand their expectations and preferences, and ensuring that designers and AI system managers, including third parties, understand the critical importance of confidentiality in this new ecosystem;

- $\quad$ supervision of involved third parties: AI services involve third parties (mainly in the programming and maintenance of systems), and this involvement increases the importance of the duty to inform clients, to exercise independent judgment, to provide sincere advice and other ongoing obligations to former clients;

- $\quad$ communication with clients: if AI is used in a way that meets all the needs of a client, it will be necessary to collect, search for data, format and use the client's especially sensitive information in 
new ways. Therefore, communication with customers is of paramount importance. Lawyers should discuss with clients the potential risks to their information, as well as the fundamental nature of AI as a means of assisting representation. But the mere tension between these ethical obligations should not, in itself, prevent the responsible (and potentially transformative and beneficial) implementation of AI services, provided the needs are met and the preferences of the sufficiently informed client are respected;

- $\quad$ independent judgment and sincere advice: a lot of information (such as confidential or shameful information about the client, the attorney's instinctive knowledge and relevant non-legal factors that AI may not have access to) may not be stored in data. Thus, in relation to a client's preferences, information that drives a lawyer's professional judgment should not be marginalized if AI is adopted;

- $\quad$ obligations to ex-clients: contrary to what happened in the past, when lawyers could simply eliminate client information at some point, there is a disincentive to discard so today, which means that such data may not only exist, but also be in use indefinitely. To preserve trust between clients and lawyers in the AI era, protection of all personal information must be guaranteed, so that clients can rely on AI as a tool in their cases.

Obviously, obtaining valid consent implies an understanding of the nature and purpose of outsourcing by the attorney and the client - and outsourcing to AI may require a more detailed explanation than outsourcing to other humans. Clients who may be unfamiliar with AI may question the performance of legal tasks by AI, what is the reason for the use of such apparatus by the lawyer and what will be the cost related to that use. In fact, ABA's opinions about outsourcing explain that, in most circumstances (and unless otherwise agreed), a lawyer should charge the client only the net costs of outsourcing, with a possible additional fee for the attorney's time to supervise and review the work product.

Lawyers must scrutinize the AI developer for contracted legal services on how and where the work will be performed, the qualifications of its employees, what security measures protect the data and about privacy rules that are relevant to the case. Another fundamental measure for lawyers is to guarantee the existence of a conflict verification mechanism, so that the opposing parties in a case or both parties in a transactional issue do not keep the same supplier (which corroborates with art. 17 of the Code of Ethics of OAB). And as for confidentiality, an agreement that binds the AI supplier and its employees must be integrated with the terms of the service provided by the AI supplier - as the strength of a confidentiality contract partially dependent on the supplier's data security protocol. 
As seen earlier, AI tools perform some tasks better, or at a lower cost, or both, when compared to human lawyers. Thus, they should be used only when, considering the risks, there are benefits to the clients. This obligation with regard to legal accountability requires that lawyers keep abreast of technological changes in relation to best practices (that is, knowing and applying technology also becomes an obligation for the lawyer, when there are tools derived from it that represent the state of the art, for example), including the benefits and risks associated with the relevant technology (HRICIK; MORGAN; WILLIAMS, 2018). This assessment requires proper dilution of the practical and legal risks of the technology, and comparison with the benefits it brings to a representation. But it also requires the application of professional rules, which can happen in a consistent assessment of two crucial determinations for the use of technology by the lawyer: if the tool fulfills its role in a reasonably competent way; and whether a competent tool can be used in a way that also complies with the lawyer's ethical obligations (which, for example, refers to the rule of confidentiality between lawyer and client, should apply to the automated tool). Another series of professional ethical rules is also presented:

- $\quad$ to ensure that the lawyer (or the client, when applicable) is the owner (or licensee) of intellectual property rights in any product created by the tool;

- $\quad$ the lawyer must be competent to review the work, and must remain responsible for the work;

- $\quad$ the amounts charged for the service must be reasonable;

- $\quad$ the lawyer may need to inform the client that he/she is using the service;

- $\quad$ the attorney must take reasonable care to protect client confidentiality while the service is using client information, and while that information is part of the service;

- $\quad$ the lawyer must take reasonable care to avoid conflicts of interest;

- $\quad$ one should also avoid corroborating with legally unauthorized practice.

An interesting issue from a professional/ethical point of view also occurs with the so-called legal professional privilege - which authorizes parties in legal proceedings to oppose the disclosure of communications, being assigned to communications between a client and his/her lawyers in connection with the provision of legal advice. As technology is increasingly integrated into legal practice, it is important to question whether legal advice provided by a robot (an AI, for example) is covered by professional privilege (STOCKDALE; MITCHELL, 2019).

The logic behind professional privilege applies to communications between a client and an AI that provides legal advice, as allowing a client to organize their business in accordance with the relevant legal provisions is in the public interest and, in that sense, total sincerity is promoted for the ability to maintain the confidentiality of communications between client and consultant. Professional 
privilege in legal advice under current law could, in principle, be applied to communications between customers and robots. However, it remains to be seen whether the courts will extend the privilege in this way and would consider that decision. If the Legislative branch (or, in the Brazilian case, the $\mathrm{OAB}$ as well) would classify a robot as a member of one of the legal professions and give advice that qualifies as legal advice for the purposes of the privilege, this would be facilitated.

If a totally autonomous robot can be considered a qualified lawyer, the privilege of legal advice can be attributed to communications between the client and the robot. But if it cannot be considered a qualified attorney (although it has been programmed to offer legal advice), the privilege will not be linked to communications with the client. Currently, technology does not seem to be capable of producing a robot that has the combination of knowledge, skills and ethical awareness that would allow its qualification as a member of one of the legal professions. In addition, for a robot to qualify as a lawyer, statutory intervention would be necessary to change, in order to cover machines and people, or giving robots the legal status of people.

\section{CONCLUSIONS}

AI will bring the daily challenge of transition to advocacy - which challenges office business models based on traditional hierarchical, opaque and monopolistic views. A symbiotic humanmachine vision, combined with an understanding of what the real potentials of AI use are, reveal that the use of smart machines in advocacy can bring benefits to the profession and to society, by making advocacy more accessible, less costly and more dedicated to services much more inherent to the essence of the profession than to repetitive tasks performed by other professionals. Thus, the advisory functions performed by lawyers - such as litigation prevention, tax planning, forecasting the demands that consumers may have in relation to products and services, and any other activity aimed at preventing litigation and costs - can have great value for companies' managers, who can thus bring lawyers closer to the strategic decision-making nucleus of their organizations.

It is true that, at present, $\mathrm{AI}$ is not still sufficient to be fully and blindly trusted in important tasks such as the defense of litigants and the interpretation/decision about their rights. In fact, even in less delicate tasks (for example, in the search for precedents), AI systems suffer from a series of defects: the algorithmic and data bias distorting analyzes and results; problems with the logic of inference and prediction of machines; morphological and semantic limitations of AI (which operates with natural language understanding); and unpredictability of systems - which, being selfprogrammable, can develop their own logic, incomprehensible even to their programmers. 
Fatalistic narratives about the inevitable replacement of lawyers by AI must be mitigated by an adaptive vision, which takes into account the context of each community of professionals (their historical, cultural, social, practical, and ethical peculiarities). Technology can facilitate access to justice and the observation of its interaction with the law can demonstrate how atavistic the profession can be demonstrated. Thus, it is essential to develop an ethics of adaptability for professionals, which balances the possibility of best practices with an ethics committed to the rule of law, access to justice and the development of best practices for the client.

The probability of replacement of a lawyer by an AI device, or having an assistant in such an apparatus - thus becoming for him / her an important auxiliary tool of augmented intelligence will depend on the type of service he/she offers. If the lawyer is a professional who performs traditional law, his/her professional future will certainly be of replacement. But professionals who, in addition to carrying out the traditional activities of a lawyer, are able to adapt to other legally relevant functions (related to dialogue and negotiation, participation in the development of new digital tools and the understanding of legally relevant issues that are much more complex than those presented by the most common litigations), will consider AI an important auxiliary tool.

Legal education adapted to the needs related to the use of AI, as well as audit services and classification of databases and AI systems, the development of algorithmic transparency in the regulation of the use of tools, and the creation of a self-explanatory AI, are possible solutions presented by the specialists in AI and law. Thus, the question about the defense and judgment of human legal issues by robots should not be restricted to the hard sciences: they must be in constant transdisciplinary dialogue with law, philosophy and ethics, in order to verify how acceptable a machine will be on representing humans in such complex and delicate legal tasks. But currently, the best available means to avoid the distortions that legal AI can cause are performing good practices represented mainly by the use of various AI systems, the variety in the search terms entered, and the continuity in human monitoring.

There are many tasks performed by lawyers, related to the treatment of contingencies beyond standardization (such as identifying idiosyncrasies of affective relationships, or personal peculiarities of clients or cases, etc.) that are still far from being replicated by machines. Although every day there is an increasing development of technologies such as affective computing (used to recognize patterns in human expressions that convey feelings), the professional lawyer still has space in the issues that demand human relationship.

Critical thinking enhanced by sufficient technical knowledge, which keep lawyers always skeptical about what can (or not) be offered by new technologies is the greatest virtue of the lawyer 
of the future. This, together with the maintenance of the essential values of the rule of law - even in situations of political and economic pressure for greater efficiency in dispute resolution - is what should be expected from lawyers, along with other skills specifically related to advocacy. In this sense, transdisciplinary skills should be developed by the future lawyer. It is not necessarily a matter of learning to code in higher education: rather, it is about understanding the impacts that technologies bring to the professional environment in which they will be inserted, developing interpersonal skills, developing their curiosity and engagement, and dedicating themselves more and more to listening and understanding the clients' interests. In fact, in addition to the law/technology transdisciplinarity, it will be essential for the lawyer to develop emotional intelligence in the face of an extremely changeable framework for his/her profession when the mass adoption of AI in law occur. Learning to communicate with others and gaining resilience are essential characteristics for a career that will undergo even greater mutations at a faster pace.

The greater precision that AI tools can bring to advocacy will likely, in the future, demand their use by professionals - releasing clients from guesses or conjectures that are little (or nothing) accurate in the provision of legal services. Thus, it can be seen that competence and diligence in the profession, true legal duties, will be interpreted as having to be integrated by the use of AI by professionals. On the other hand, there are several unknowns about the use of such tools - and here it should be highlighted, mainly, the current lack of explicability of the process of elaborating the advice by such machines, as well as the human prejudices that can come to tarnish the information processing - which must be resolved before the widespread use of AI become recommended by the accreditation, standardization and law enforcement agencies.

The professional privilege of confidentiality in the advice provided by a lawyer to clients could also be extended to the advice given by AI systems, in principle - because the underlying logic that guides the relationship between human lawyer and client also lends itself to client-machine communication. However, there are logical and philosophical implications behind this questioning which would require considering the machine as being legally comparable to a person. AI does not yet have capabilities similar to human intelligence, however. So, issues of this type would require changes to the legislation pertaining to ethics in advocacy.

An interesting solution for the regulation of AI, as long as there is no specific deontology for its use in law yet, is to treat it analogously to the outsourcing of legal services, and always with respect for fundamental ethical principles in the lawyer's conduct - competence, diligence, communication, confidentiality, supervision of assistance by other lawyers and, especially with 
regard to obtaining the clients' consent before using the $\mathrm{AI}$ - all of these principles that find correspondence in the OAB Statute and in the entity's Code of Ethics.

\section{REFERENCES}

BRASIL. Conselho Federal da Ordem dos Advogados do Brasil. Código de Ética e Disciplina da OAB. Brasília, DF, 13 de fevereiro de 1995.

BRASIL. Lei n ${ }^{0}$ 10.406, de 10 de janeiro de 2002. Institui o Código Civil. Brasília, DF, Diário Oficial da União, 11.01.2002.

BRASIL. Lei $n^{\circ}$ 6.015, de 31 de dezembro de 1973. Dispõe sobre os registros públicos, e dá outras providências. Brasília, DF, Diário Oficial da União, 31.12.1973 e retificado em 30.10.1975.

BRASIL. Lei n ${ }^{\circ}$ 8.906, de 4 de julho de 1994. Dispõe sobre o Estatuto da Advocacia e a Ordem dos Advogados do Brasil (OAB). Brasília, DF, Diário Oficial da União, 5.07.1994.

CARREL, Alyson. Legal Intelligence Through Artificial Intelligence Requires Emotional Intelligence: A New Competency Model for the 21st Century Legal Professional. Ga. St. U. L. Rev., [s. l.], v. 35, n. 4, p. 1152-1183, 2019.

FLOOD, John A. Legal Professionals of the Future: Their Ethos, Role and Skills. SSRN, [s. l.], 2019. DOI: http://dx.doi.org/10.2139/ssrn.3315855.

HAUPT, Claudia E. Governing A.I.'s Professional Advice. McGill Law Journal, [s. l.], v. 64, n. 4, p. 666-682, 2020. Available from: https://bit.ly/3aJ86s2 [Accessed: 15 Apr. 2021].

HRICIK, David; MORGAN, Asya-Lorrene S.; WILLIAMS, Kyle H. Ethics of Using Artificial Intelligence to Augment Drafting Legal Documents. Texas A\&M Journal of Property Law, [s. l.], v. 4, n. 5, p. 465-484, 2018. Available from: https://bit.ly/3tXr9qc [Accessed: 15 Apr. 2021].

HU, Teng; LU, Huafeng. Study on the Influence of Artificial Intelligence on Legal Profession. Proceedings of the 5th International Conference on Economics, Management, Law and Education (EMLE 2019). Paris: Atlantis Press, 2020. p. 964-968. Available from: https://bit.ly/3eGdmOu [Accessed: 15 Apr. 2021].

IVEY, Matthew. The Ethical Midfield in Artificial Intelligence: Practical Reflections for National Security Lawyers. The Georgetown Journal of Legal Ethics, [s. l.], v. 33, n. 1, p. 109-138, 2020. Available from: https://bit.ly/32PG4qs [Accessed: 15 Apr. 2021].

JACOBOWITZ, Jan L.; ORTIZ, Justin. Happy Birthday Siri! Dialing in Legal Ethics for Artificial Intelligence, Smartphones, and Real Time Lawyers. Texas A\&M Journal of Property Law, [s. l.], v. 4, n. 5, p. 407-442, 2018. Available from: https://bit.ly/2RZf4m8 [Accessed: 15 Apr. 2021].

KERIKMÄE, Tanel; HOFFMANN, Thomas; CHOCHIA, Archil. Legal Technology for Law Firms: Determining Roadmaps for Innovation. Croatian International Relations Review, [s. l.], v. XXIV, n. 81, p. 91-112, 2018. DOI: https://doi.org/10.2478/cirr-2018-0005. 
MARKOVIC, Milan. Rise of the Robot Lawyers? Arizona Law Review, [s. l.], v. 61, n. 2, p. 325350, 2019. Available from: https://bit.ly/3aI1b2l [Accessed: 15 Apr. 2021].

MCGOOGAN, Cara. 19-year-old's 'robot lawyer' overturns 160,000 parking tickets. The Telegraph, [s. l.], 26 June 2016. Available from: https://bit.ly/3xrzx3i [Accessed: 15 Apr. 2021].

MOSES, Lyria Bennett. The Need for Lawyers. In: The Future of Australian Legal Education (University of New South Wales Law Research Series, Research Paper No. 18-46). Sydney: Thomson Reuters, 2018. 15 p. DOI: http://dx.doi.org/10.2139/ssrn.3225456.

NUNEZ, Catherine. Artificial Intelligence and Legal Ethics: Whether AI Lawyers Can Make Ethical Decisions. Tulane Journal of Technology and Intellectual Property, [s. l.], v. 20, p. 189204, 2017. Available from: https://bit.ly/3sRbZl3 [Accessed: 15 Apr. 2021].

ROGERS, Justine; BELL, Felicity. The Ethical AI Lawyer: What is Required of Lawyers When They Use Automated Systems? Law, Technology and Humans, [s. l.], v. 1, n. 1, p. 80-99, 2019. DOI: https://doi.org/10.5204/lthj.v1i0.1324.

ROZADO, David. Wide range screening of algorithmic bias in word embedding models using large sentiment lexicons reveals underreported bias types. PLoS ONE, [s. l.], v. 15, n. 4, e0231189, 2020. DOI: https://doi.org/10.1371/journal.pone.0231189.

SADO, Fatai et al. Explainable Goal-Driven Agents and Robots - A Comprehensive Review and New Framework. ArXiv Cornell University, [s. l.], 2020. Available from: https://bit.ly/2QAbEWK [Accessed: 15 Apr. 2021].

SILVA, Alexandre Pacheco da; FABIANI, Emerson Ribeiro; FEFERBAUM, Marina (coord.). O Futuro das Profissões Jurídicas: você está preparad@? Sumário Executivo da Pesquisa Quantitativa Tecnologia, Profissões e Ensino Jurídico”. São Paulo: Fundação Getúlio Vargas, 2018. Available from: https://bit.ly/3dVzKnR [Accessed: 15 Apr. 2021].

SIMPSON, Brian. Algorithms or advocacy: does the legal profession have a future in a digital world? Information \& Communications Technology Law, [s. l.], v. 25, n. 1, p. 50-61, 2016. DOI: https://doi.org/10.1080/13600834.2015.1134144.

SIMSHAW, Drew. Ethical Issues in Robo-Lawyering: The Need for Guidance on Developing and Using Artificial Intelligence in the Practice of Law. Hastings Law Journal, [s. l.], v. 70, n. 1, p. 173-214, 2019. Available from: https://bit.ly/3vkWFi4 [Accessed: 15 Apr. 2021].

SMITH, Alexander; SPENCER, Nigel. Do Lawyers Need to Learn to Code? A Practitioner Perspective on the 'Polytechnic' Future of Legal Education. In: DENVIR, Catrina (ed.). Modernising Legal Education. Cambridge: Cambridge University Press, 2020. p. 18-37.

STOCKDALE, Michael; MITCHELL, Rebecca. Legal Advice Privilege and Artificial Legal Intelligence: Can Robots Give Privileged Legal Advice? The International Journal of Evidence \& Proof, [s. l.], v. 23, n. 4, p. 422-439, 2019. DOI: https://doi.org/10.1177/1365712719862296. 
STRICKSON, Benjamin; IGLESIA, Beatriz De La. Legal Judgement Prediction for UK Courts. In: ICISS 2020: Proceedings of the 3rd International Conference on Information Science and System. March 2020. p. 204-209. DOI: https://doi.org/10.1145/3388176.3388183.

SUSSKIND, Richard. Tomorrow's Lawyers: An Introduction to Your Future. 2. ed. Oxford: Oxford University Press, 2017.

TUNG, Kenneth. AI, the internet of legal things, and lawyers. Journal of Management Analytics, [s. l.], v. 6, n. 4, p. 390-403, 2019. DOI: https://doi.org/10.1080/23270012.2019.1671242.

TURNER, Karen. Meet Ross”, the newly hired legal robot. The Washington Post, [s. l.], 16 May 2016. Available from: https://wapo.st/3xDC3Um [Accessed: 15 Apr. 2021].

WALTERS, Ed. The Model Rules of Autonomous Conduct: Ethical Responsibilities of Lawyers and Artificial Intelligence. Georgia State University Law Review, [s. l.], v. 35, n. 4, p. 1072-1092, 2019. Available from: https://bit.ly/3vstSs7 [Accessed: 15 Apr. 2021].

WEBLEY, Lisa et al. The Profession(s)' Engagements with LawTech: Narratives and Archetypes of Future Law. Law, Technology and Humans, [s. l.], v. 1, n. 1, p. 6-26, 2019. DOI: https://doi.org/10.5204/lthj.v1i0.1314.

YOON, Albert H. The post-modern lawyer: Technology and the democratization of legal representation. University of Toronto Law Journal, [s. l.], v. 66, n. 4, p. 456-471, 2016. DOI: https://doi.org/10.3138/UTLJ.4007.

YU, Ronald; ALÌ, Gabriele Spina. What's Inside the Black Box? AI Challenges for Lawyers and Researchers. Legal Information Management, [s. l.], v. 19, n. 1, p. 2-13, 2019. DOI: https://doi.org/10.1017/S1472669619000021. 